\title{
Effect of $\mathrm{BiScO}_{3}$ Additive on the Structure and Electrical Properties of the $\mathrm{Y}_{2} \mathrm{O}_{3}-\mathrm{ZrO}_{2}-\mathrm{SrTiO}_{3}$ System
}

\author{
I.V. Sudzhanskaya ${ }^{1}$, M.N. Yaprintsev ${ }^{1}$, Yu.S. Nekrasova ${ }^{2}$, V.M. Beresnev ${ }^{3}$, A.N. Vasilev ${ }^{1}$ \\ ${ }^{1}$ Belgorod National Research University, 85, Pobeda Str., 308015, Belgorod Russia \\ 2 Belgorod State Technological University named after V.G. Shukhov, 46, Kostyukov Str, 308012 Belgorod, Russia \\ ${ }^{3}$ N. Karazin Kharkiv National University, 2, Svoboda Sq, 61000 Kharkov, Ukraine
}

(Received 26 December 2018; revised manuscript received 08 February 2019; published online 25 February 2019)

\begin{abstract}
Samples of ceramic systems $\mathrm{Y}_{2} \mathrm{O}_{3}-\mathrm{ZrO}_{2}-\mathrm{SrTiO}_{3}$ and $\mathrm{Y}_{2} \mathrm{O}_{3}-\mathrm{ZrO}_{2}-\mathrm{SrTiO}_{3}-\mathrm{BiScO}_{3}$ were obtained. It was established that $\mathrm{Y}_{2} \mathrm{O}_{3}-\mathrm{ZrO}_{2}-\mathrm{SrTiO}_{3}$ is two-phase: the phase with the cubic structure $P m \overline{3} m$, belonging to $\mathrm{SrTiO}_{3}$, and the phase with the tetragonal structure $(P 42 / n m c)$, belonging to $\mathrm{Y}_{0.05} \mathrm{Zr}_{0.95} \mathrm{O}_{2}$. The introduction of the $\mathrm{BiScO} 3$ component into the $\mathrm{Y}_{2} \mathrm{O}_{3}-\mathrm{ZrO}_{2}-\mathrm{SrTiO}_{3}$ system leads to the formation of three phases: the cubic phase with the space symmetry group $F m \overline{3} m$, the cubic phase with $P m \overline{3} m$ symmetry, and the tetragonal phase with $P 4 m m$ symmetry. The reflexes from the cubic phase of $F m \overline{3} m$ belong to the cubic modification of zirconia. The cubic phase of $P m \overline{3} m$ and the tetragonal phase of $P 4 m m$ belong to $\mathrm{SrTiO}_{3}-\mathrm{BiScO}_{3}$. Using scanning electron microscopy, it was shown that the addition of $\mathrm{BiScO}_{3}$ additive to the $\mathrm{Y}_{2} \mathrm{O}_{3}-\mathrm{ZrO}_{2}$ $\mathrm{SrTiO}_{3}$ ceramic system leads to a significant decrease in the grain size and greater homogeneity of the material.

Based on the analysis of the results of studies of the specific electrical conductivity of the ceramic systems $\mathrm{Y}_{2} \mathrm{O}_{3}-\mathrm{ZrO}_{2}-\mathrm{SrTiO}_{3}$ and $\mathrm{Y}_{2} \mathrm{O}_{3}-\mathrm{ZrO}_{2}-\mathrm{SrTiO}_{3}-\mathrm{BiScO}_{3}$, the introduction of the $\mathrm{BiScO}_{3}$ additive into the ceramic system reduces the activation energy of the conductivity process from $1.5 \mathrm{eV}$ to $0.82 \mathrm{eV}$.
\end{abstract}

Keywords: Ceramic system, X-ray phase composition, Microstructure, Conductivity.

DOI: 10.21272/jnep.11(1).01018

PACS numbers: PACS numbers: 81.05.Je, 72.80.Ey

\section{INTRODUCTION}

One of the dynamically developing areas of hydrogen energy remains the development of solid oxide fuel cells (SOFC) due to their high efficiency of converting the chemical energy of hydrogen-containing fuel into electrical energy, silent operation, low toxicity [1]. Among the wide range of materials for the production of solid SOFC electrolytes in the high-temperature region, ceramic materials based on $\mathrm{Y}_{2} \mathrm{O}_{3}-\mathrm{ZrO}_{2}$ are the most popular [2-3]. However, $\mathrm{Y}_{2} \mathrm{O}_{3}-\mathrm{ZrO}_{2}$ achieves high conductivity at temperatures of $1000-1200 \mathrm{~K}$ [4]. To reduce the operating temperature, two approaches are applied: the use of thin-film coatings or the development of new systems operating at lower temperatures.

One of the first systems of thin-film electrolytes is the development of $\mathrm{ZrO}_{2}: \mathrm{Y}_{2} \mathrm{O}_{3} / \mathrm{SrTiO}_{3}$ heterostructures [5], ensuring the presence of voids in the coating structure along the $\mathrm{ZrO}_{2}: \mathrm{Y}_{2} \mathrm{O}_{3} / \mathrm{SrTiO}_{3}$ interfaces for the transport of oxygen ions associated with the disordering of the oxygen sublattice near the interface, which results to an increase in conductivity at lower temperatures.

An increase in the conductivity of bulk ceramic systems based on $\mathrm{ZrO}_{2} / \mathrm{SrTiO}_{3}$ is observed at temperatures above $650 \mathrm{~K}[6,7]$.

The creation of solid solutions of multicomponent ceramic systems leads to the production of materials with desired properties, including those with high oxygen-ionic conductivity. The addition of $\mathrm{BiScO}_{3}$ to the $\mathrm{Y}_{2} \mathrm{O}_{3}-\mathrm{ZrO}_{2}-\mathrm{SrTiO}_{3}$ system can result in a solid solution with high oxygen-ionic conductivity due to an increase in the structural disorder of the material and high ionic conductivity of $\mathrm{Bi}_{2} \mathrm{O}_{3}$ [8].

The purpose of this work was to determine the in- fluence of $\mathrm{BiScO}_{3}$ on the structure and electrical properties of the $\mathrm{Y}_{2} \mathrm{O}_{3}-\mathrm{ZrO}_{2}-\mathrm{SrTiO}_{3}$ system.

\section{DESCRIPTION OF THE OBJECT AND METHODS OF STUDY}

Obtaining samples of the $\mathrm{Y}_{2} \mathrm{O}_{3}-\mathrm{ZrO}_{2}-\mathrm{SrTiO}_{3}$ ceramic system with the composition $0.025 \mathrm{Y}_{2} \mathrm{O}_{3}, 0.475 \mathrm{ZrO}_{2}$, $0.5 \mathrm{SrTiO}_{3}$ consisted in the synthesis of $\mathrm{SrTiO}_{3}$ from a mixture of strontium carbonate $\mathrm{SrCO}_{3}$ and titanium dioxide $\mathrm{TiO}_{2}$ annealed at $1623 \mathrm{~K}$ for 2 hours. The next step was to obtain a composition of $0.025 \mathrm{Y}_{2} \mathrm{O}_{3}$, $0.475 \mathrm{ZrO}_{2}$, $0.5 \mathrm{SrTiO}_{3}$ from a mixture of powders of synthesized strontium titanate and $\mathrm{Y}_{0.05} \mathrm{Zr}_{0.95} \mathrm{O}_{2}$, taken in a stoichiometric ratio. The mixture of powders was annealed at a temperature of $1623 \mathrm{~K}$ for 2 hours.

Samples of the $\mathrm{Y}_{2} \mathrm{O}_{3}-\mathrm{ZrO}_{2}-\mathrm{SrTiO}_{3}-\mathrm{BiScO}_{3}$ ceramic system with the composition of $0.025 \mathrm{Y}_{2} \mathrm{O}_{3}, 0.475 \mathrm{ZrO}_{2}$, 0.3, 0.2 $\mathrm{BiScO}_{3}$ were obtained according to the technology developed by us earlier in [9-10] as follows: previously synthesized $\mathrm{SrTiO}_{3}$ powder and $\mathrm{Bi}_{2} \mathrm{O}_{3}$ and $\mathrm{Sc}_{2} \mathrm{O}_{3}$ oxides taken in stoichiometric ratio, were thermally treated at a temperature of $1523 \mathrm{~K}$ for 2 hours. The thus obtained powder and powder of zirconium dioxide stabilized with yttrium $\mathrm{Y}_{0.05} \mathrm{Zr}_{0.95} \mathrm{O}_{2}$, taken in a stoichiometric ratio, were mixed in an agate mortar with the addition of ethyl alcohol for 4 hours. The received suspension was dried at $373 \mathrm{~K}$ for 1 hour.

Compaction of samples with a diameter of $10 \mathrm{~mm}$ and a thickness of $1 \mathrm{~mm}$ was performed by the method of biaxial pressing at a pressure of $70 \mathrm{MPa}$. Sintering of the samples was carried out at a temperature of $1543 \mathrm{~K}$ for 2 hours in an atmosphere of air. The phase composition of the material obtained was determined using an Rigaku Ultima IV X-ray diffractometer. The study of 
the microstructure was carried out using a Quanta 200 $3 \mathrm{D}$ raster ion-electron microscope, and the measurement of electrical conductivity $\sigma$ and dielectric characteristics was performed on an Novocontrol Concept 43 impedance meter with alternating current.

\section{DESCRIPTION AND ANALYSIS OF THE RESULTS}

The diffractogram of the $\mathrm{Y}_{2} \mathrm{O}_{3}-\mathrm{ZrO}_{2}-\mathrm{SrTiO}_{3}$ ceramic system obtained at room temperature is shown in Fig. 1.

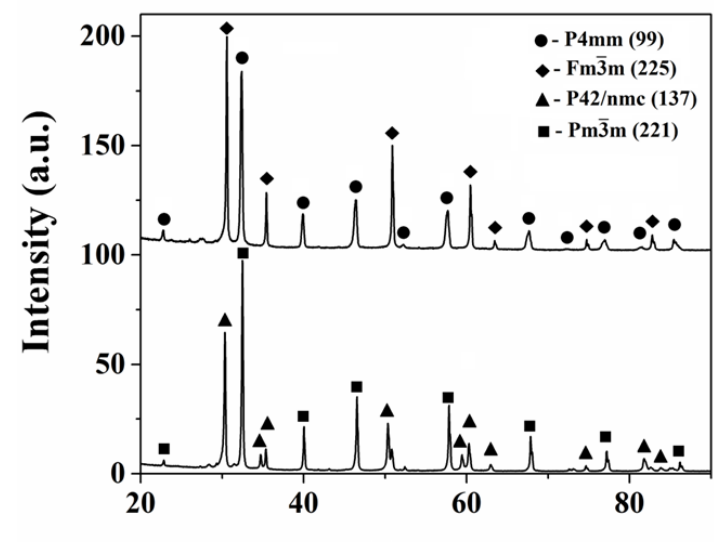

$2 \theta$, deg.

Fig. 1 - Diffractogram of the samples of the $\mathrm{Y}_{2} \mathrm{O}_{3}-\mathrm{ZrO}_{2}-\mathrm{SrTiO}_{3}$ ceramic system: $\mathbf{\Delta}$-tetragonal $P 42 / n m c$ phase; $\bullet$-cubic $F m \overline{3} m$-phase; • - tetragonal P4mm-phase; - cubic $P m \overline{3} m$ phase

Based on the analysis of the diffractogram, it was found that the obtained $\mathrm{Y}_{2} \mathrm{O}_{3}-\mathrm{ZrO}_{2}-\mathrm{SrTiO}_{3}$ ceramic system is two-phase: a phase with a cubic structure (space symmetry group $P m \overline{3} m$ ) and a phase with a tetragonal structure $(P 42 / n m c)$. The reflexes from the cubic phase belong to $\mathrm{SrTiO}_{3}$. The phase with tetragonal structure belongs to $\mathrm{Y}_{0.05} \mathrm{Zr}_{0.95} \mathrm{O}_{2}$.

The introduction of the $\mathrm{BiScO}_{3}$ component into the $\mathrm{Y}_{2} \mathrm{O}_{3}-\mathrm{ZrO}_{2}-\mathrm{SrTiO}_{3}$ system leads to the formation of three phases: the cubic phase with the space symmetry group $F m \overline{3} m$, the cubic phase with the symmetry $P m \overline{3} m$, and the tetragonal phase with the symmetry $P 4 \mathrm{~mm}$. Reflexes from the cubic phase of $F m \overline{3} m$ are indexed as belonging to the cubic modification of zirconium dioxide. The cubic phase of $P m \overline{3} m$ and the tetragonal phase of $P 4 m m$ belong to $\mathrm{SrTiO}_{3}-\mathrm{BiScO}_{3}$

The SEM image of the sample surface of the ceramic system $\mathrm{Y}_{2} \mathrm{O}_{3}-\mathrm{ZrO}_{2}-\mathrm{SrTiO}_{3}$ (Fig. 2a, b) obtained in the phase contrast mode indicates that there are two types of grains in the sample structure: dark gray grains and light gray grains with dimensions of several micrometers. By the method of determining the elemental composition, it was established that lighter areas correspond to $\mathrm{Y}_{2} \mathrm{O}_{3}-\mathrm{ZrO}_{2}$, dark areas - to $\mathrm{SrTiO}_{3}$.

The results of measurements of the impedance of the $\mathrm{Y}_{2} \mathrm{O}_{3}-\mathrm{ZrO}_{2}-\mathrm{SrTiO}_{3}$ and $\mathrm{Y}_{2} \mathrm{O}_{3}-\mathrm{ZrO}_{2}-\mathrm{SrTiO}_{3}-\mathrm{BiScO}_{3}$ ceramic systems are presented in Fig. 4.

The impedance spectrum of the $\mathrm{Y}_{2} \mathrm{O}_{3}-\mathrm{ZrO}_{2}-\mathrm{SrTiO}_{3}$ ceramic system obtained at a temperature of $573 \mathrm{~K}$ (Fig. 5a) clearly shows two arcs due to contributions from the grain volume, grain boundary, and growth at low frequencies associated with blocking electrodes.

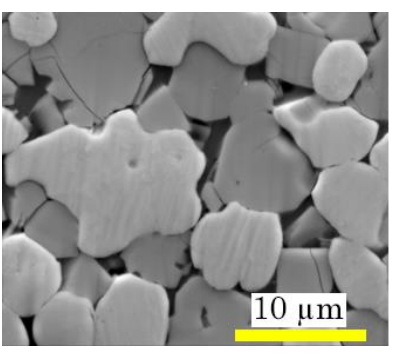

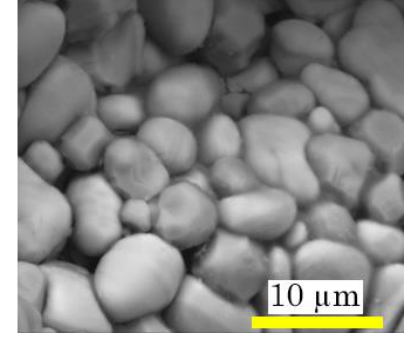

$\mathrm{b}$
Fig. 2 - SEM-image of sample surface of the $\mathrm{Y}_{2} \mathrm{O}_{3}-\mathrm{ZrO}_{2}-\mathrm{SrTiO}_{3}$ ceramic system: a) thin section; b) chip

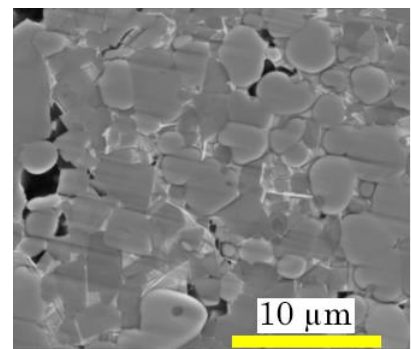

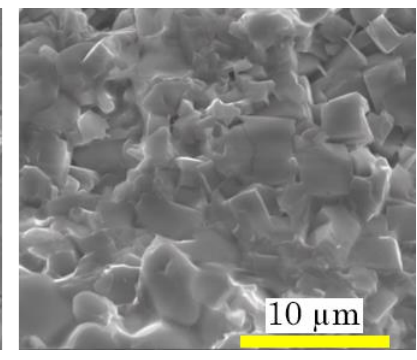

$\mathrm{b}$
Fig. 3 - SEM-image of sample surface of the ceramic system $\mathrm{Y}_{2} \mathrm{O}_{3}-\mathrm{ZrO}_{2}-\mathrm{SrTiO}_{3}-\mathrm{BiScO}_{3}$ : a) thin section; b) chip

Fig. $3 \mathrm{a}$, b shows the SEM image of the sample surface of the $\mathrm{Y}_{2} \mathrm{O}_{3}-\mathrm{ZrO}_{2}-\mathrm{SrTiO}_{3}-\mathrm{BiScO}_{3}$ ceramic system. In the presented images, grains of two types with sizes of $\sim 1$ micron are observed: grains of rounded shape and grains of rectangular shape. Using the definition of the elemental composition, it was established that grains of rounded shape correspond to the cubic $\mathrm{Fm} 3 \mathrm{~m}$ phase of zirconium dioxide. Grains having rectangular shape correspond to the compound of $\mathrm{SrTiO}_{3}-\mathrm{BiScO}_{3}$ solid solution.

The impedance spectrum of the $\mathrm{Y}_{2} \mathrm{O}_{3}-\mathrm{ZrO}_{2}-\mathrm{SrTiO}_{3}$ $\mathrm{BiScO}_{3}$ ceramic system is a single circle at high frequencies and a blocking effect at low frequencies. The impedance spectrum of ceramic materials has two semicircles indicating the contribution of the volume of grains and boundaries to the conductivity of the material. The presence of one circle in the impedance spectrum may be due to the high homogeneity of the obtained ceramic material [11], which is confirmed by images on the SEM image of a sample of the $\mathrm{Y}_{2} \mathrm{O}_{3}-\mathrm{ZrO}_{2}-\mathrm{SrTiO}_{3}-$ $\mathrm{BiScO}_{3}$ ceramic system.

The results of studies of the specific electrical conductivity of the ceramic systems $\mathrm{Y}_{2} \mathrm{O}_{3}-\mathrm{ZrO}_{2}-\mathrm{SrTiO}_{3}$ and $\mathrm{Y}_{2} \mathrm{O}_{3}-\mathrm{ZrO}_{2}-\mathrm{SrTiO}_{3}-\mathrm{BiScO}_{3}$ on an alternating current with a frequency of $1 \mathrm{kHz}$ are presented in Fig. 5 .

The temperature dependence of the electrical conductivity of ceramic systems $\mathrm{Y}_{2} \mathrm{O}_{3}-\mathrm{ZrO}_{2}-\mathrm{SrTiO}_{3}$ and $\mathrm{Y}_{2} \mathrm{O}_{3}-\mathrm{ZrO}_{2}-\mathrm{SrTiO}_{3}-\mathrm{BiScO}_{3}$ is determined according to the Arrhenius law:

$$
\sigma=\sigma_{0} \exp \left(-E_{a} / k T\right),
$$




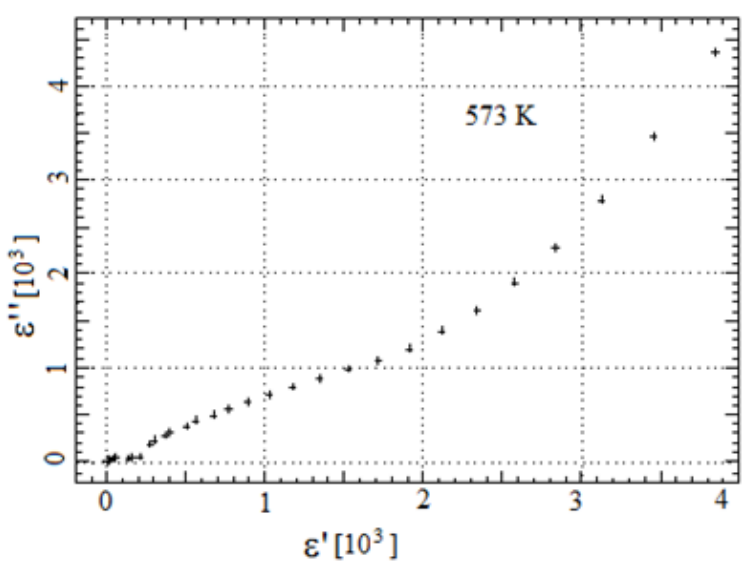

a

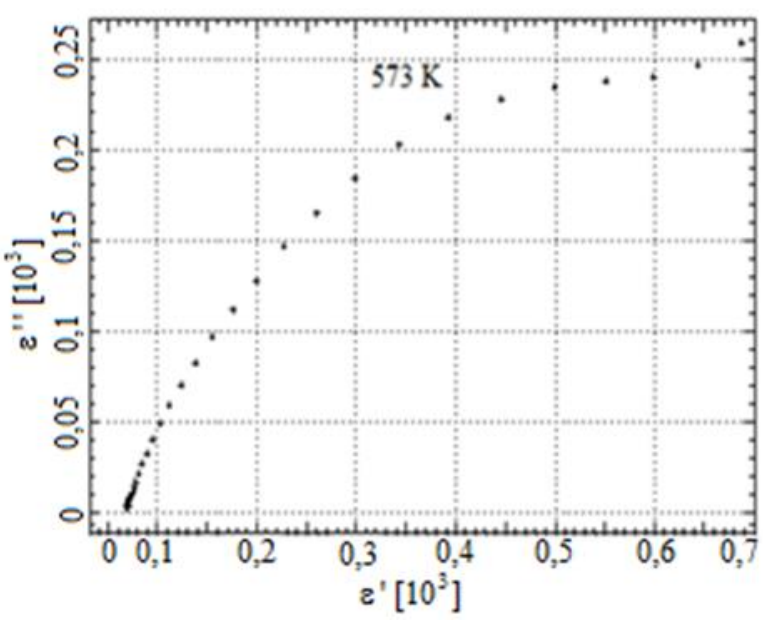

$\mathrm{b}$

Fig. 4 - The impedance spectrum of ceramic systems in coordinates $\varepsilon^{\prime}\left(\varepsilon^{\prime \prime}\right)$ : a) $\mathrm{Y}_{2} \mathrm{O}_{3}-\mathrm{ZrO}_{2}-\mathrm{SrTiO}_{3}$, b) $\mathrm{Y}_{2} \mathrm{O}_{3}-\mathrm{ZrO}_{2}-\mathrm{SrTiO}_{3}-\mathrm{BiScO}_{3}$

where $\sigma_{0}$ is the pre-exponential factor; $E_{a}$ is the activation energy of electrical conductivity; $k$ is the Boltzmann constant equal to $1.38 \cdot 10^{-23} \mathrm{~J} / \mathrm{K}$.

The activation energy of the conduction process was $1.5 \mathrm{eV}$ for the $\mathrm{Y}_{2} \mathrm{O}_{3}-\mathrm{ZrO}_{2}-\mathrm{SrTiO}_{3}$ system and $0.82 \mathrm{eV}$ for the $\mathrm{Y}_{2} \mathrm{O}_{3}-\mathrm{ZrO}_{2}-\mathrm{SrTiO}_{3}-\mathrm{BiScO}_{3}$ system. Thus, we can conclude that the introduction of the $\mathrm{BiScO}_{3}$ additive made it possible to reduce the activation energy approx-

\section{REFERENCES}

1. M. Williams, Fuel Cells 7 No 1, 78 (2007).

2. N.N. Novik, V.G. Konakov, I.Yu. Archakov, Rev. Adv. Mater. Sci. 40, 188 (2015).

3. S.P.S. Badwai, F.T. Ciacchi, Ionics 6, 1 (2000).

4. O. Yamamoto, W. Vielstich, H.A. Gasteiger, A. Lamm, Fuel Cell Technol. Appl. 4, 1002 (2003).

5. J. Garsia-Barriocanal, A. Rivera-Calzada, M. Varela, Z. Sefrioui, E. Iborra, C. Leon, S.J. Pennycook, J. Santamaria, Science 324, 465-b (2009).

6. O.N. Ivanovn, Ya.V. Trusova, Ceram. Int. 42, 5245 (2016).

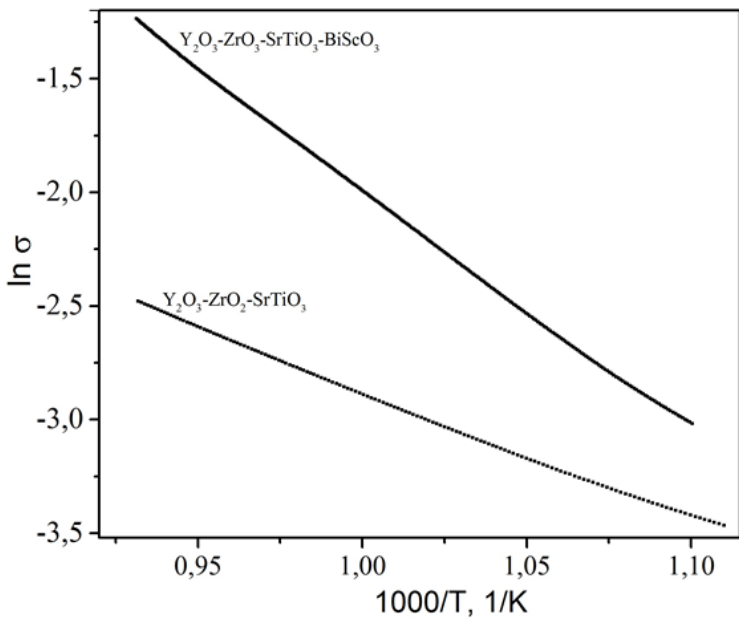

Fig. 5 - Dependence $\ln \sigma=f(1 / T)$ of samples of ceramic systems $\mathrm{Y}_{2} \mathrm{O}_{3}-\mathrm{ZrO}_{2}-\mathrm{SrTiO}_{3}$ and $\mathrm{Y}_{2} \mathrm{O}_{3}-\mathrm{ZrO}_{2}-\mathrm{SrTiO}_{3}-\mathrm{BiScO}_{3}$

imately by 2 times, and also to use the ceramic system $\mathrm{Y}_{2} \mathrm{O}_{3}-\mathrm{ZrO}_{2}-\mathrm{SrTiO}_{3}-\mathrm{BiScO}_{3}$ for the production of solidstate electrolytes.

\section{CONCLUSIONS}

1. It was found that $\mathrm{Y}_{2} \mathrm{O}_{3}-\mathrm{ZrO}_{2}-\mathrm{SrTiO}_{3}$ is two-phase: the phase with the $\operatorname{Pm} \overline{3} m$ cubic structure belonging to $\mathrm{SrTiO}_{3}$ and the tetragonal phase (P42/nmc) belonging to $\mathrm{Y}_{0.05} \mathrm{Zr}_{0.95} \mathrm{O}_{2}$. The introduction of the $\mathrm{BiScO}_{3}$ component into the $\mathrm{Y}_{2} \mathrm{O}_{3}-\mathrm{ZrO}_{2}-\mathrm{SrTiO}_{3}$ system leads to the formation of three phases: the cubic phase with the space symmetry group $F m \overline{3} m$, the cubic phase with $P m \overline{3} m$ symmetry, and the tetragonal phase with $P 4 \mathrm{~mm}$ symmetry. The reflexes from the cubic phase of $F m \overline{3} m$ belong to the cubic modification of zirconia. The cubic phase of $P m \overline{3} \mathrm{~m}$ and the tetragonal phase of $P 4 \mathrm{~mm}$ belong to $\mathrm{SrTiO}_{3}-\mathrm{BiScO}_{3}$.

2. Using scanning electron microscopy, it was shown that the addition of $\mathrm{BiScO}_{3}$ additive to the ceramic system $\mathrm{Y}_{2} \mathrm{O}_{3}-\mathrm{ZrO}_{2}-\mathrm{SrTiO}_{3}$ leads to a significant decrease in the grain size and greater homogeneity of the material.

3. It has been established that the introduction of the $\mathrm{BiScO}_{3}$ additive into the ceramic system leads to a decrease in the activation energy of the conduction process from $1.5 \mathrm{eV}$ to $0.82 \mathrm{eV}$.

7. O.N. Ivanov, I.V. Sudzhanskaya, R.A. Lyubushkin. Glass and Ceramics 72 No 9-10, 376 (2016).

8. J. Garcia-Barriocanal, A. Rivera-Calzada, M. Varela, Science 321, 676 (2008)

9. O.N. Ivanov, I.V. Sudzhanskaya, M.N. Yapryntsev. Glass and Ceramics 72 No 11 - 12, 413 (2016).

10. I.V. Sudzhanskaya, V.M. Beresnev, L.O. Iliushyn, J. NanoElectron. Phys. 10, 04024 (2018).

11. S.V. Gnedenkov, S.L. Sinebryukov, Vestnik of the Far East Branch of the Russian Academy of Sciences 5, 6 (2006). 


\section{Вплив домішки $\mathrm{BiScO}_{3}$ на структуру та електричні властивості системи $\mathrm{Y}_{2} \mathrm{O}_{3}-\mathrm{ZrO}_{2}-\mathrm{SrTiO}_{3}$}

\section{І.В. Суджанськаㄹ, М.Н. Япринцев ${ }^{1}$ Ю.С. Некрасова ${ }^{2}$, В.М. Береснев ${ }^{3}$, А.Н. Васильев ${ }^{1}$}

1 Белгородський державний національний дослідницький університет, вул. Перемоги, 85, 308015 Белгород, Росія

2 Белгородський державний технологічний університет іл. Шухова, вул. Костюкова, 46, 308012 Белгород, Росія

${ }^{3}$ Харківский національний університет іл. В.Н. Каразіна, пл. Свободи, 4, 61022 Харків, Украӥна

В роботі отримано зразки керамічних систем $\mathrm{Y}_{2} \mathrm{O}_{3}-\mathrm{ZrO}_{2}-\mathrm{SrTiO}_{3}$ і $\mathrm{Y}_{2} \mathrm{O}_{3}-\mathrm{ZrO}_{2}-\mathrm{SrTiO}_{3}-\mathrm{BiScO}_{3}$. Встановлено, що $\mathrm{Y}_{2} \mathrm{O}_{3}-\mathrm{ZrO}_{2}-\mathrm{SrTiO}_{3}$ є двофазною і складається із фази з кубічною структурою $(P m \overline{3} m)$, що належить до $\mathrm{SrTiO}_{3}$, і фази 3 тетрагональною структурою $(P 42 / n m c)$, що належить до $\mathrm{Y}_{0.05} \mathrm{Zr}_{0.95} \mathrm{O}_{2}$. Введення компонента $\mathrm{BiScO}_{3}$ у систему $\mathrm{Y}_{2} \mathrm{O}_{3}-\mathrm{ZrO}_{2}-\mathrm{SrTiO}_{3}$ призводить до утворення трьох фаз: кубічної фази з групою симетрї̈ простору $F m \overline{3} m$, кубічної фази з симетрією $P m \overline{3} m$ та тетрагональної фази 3 симетрією $P 4 \mathrm{~mm}$. Рефлекси від кубічної фази $F m \overline{3} m$ належать до кубічної модифікації діоксиду цирконію. Кубічна фаза $P m \overline{3} m$ і тетрагональна фаза $P 4 m m$ належать до $\mathrm{SrTiO}_{3}-\mathrm{BiScO}_{3}$. За допомогою скануючої електронної мікроскопії було показано, що додавання добавки $\mathrm{BiScO}_{3}$ до керамічної системи $\mathrm{Y}_{2} \mathrm{O}_{3}-\mathrm{ZrO}_{2}-\mathrm{SrTiO}_{3}$ призводить до значного зменшення розміру зерен і більшої однорідності матеріалу. Аналіз результатів досліджень питомої електропровідності керамічних систем $\mathrm{Y}_{2} \mathrm{O}_{3}-\mathrm{ZrO}_{2}-\mathrm{SrTiO}_{3}$ i $\mathrm{Y}_{2} \mathrm{O}_{3}-\mathrm{ZrO}_{2}-\mathrm{SrTiO}_{3}-\mathrm{BiScO}_{3}$ свідчить, що введення добавки $\mathrm{BiScO}_{3}$ в керамічну систему зменшуе енергію активації процесу провідності від $1.5 \mathrm{eB}$ до $0.82 \mathrm{eB}$.

Ключові слова: Керамічна система, Рентгенофазовий склад, Мікроструктура, Питома електропровідність. 